\title{
EVALUASI KESESUAIAN LAHAN TANAMAN UBI JALAR (Ipomoea batatas L.) DENGAN MEMANFAATKAN APLIKASI SPKL DI KECAMATAN CIAMPEA, KABUPATEN BOGOR, JAWA BARAT \\ Land Suitability Evaluation of Sweet Potato (Ipomoea batatas L.) by Utilizing SPKL Application in the Ciampea District, Bogor, West Java
}

\author{
Aldila Raffaelia Rosani ${ }^{1}$, Soemarno ${ }^{1 *}$, Yiyi Sulaeman ${ }^{2}$ \\ Jurusan Tanah, Fakultas Pertanian, Universitas Brawijaya Jl. Veteran No.1 Malang, Jawa Timur 65145 \\ Balai Besar Penelitian dan Pengembangan Sumberdaya Lahan Pertanian, Bogor Jl. Tentara Pelajar No.12 \\ Cimanggu, Bogor 16111 \\ *Penulis korespondensi: soemarno@ub.ac.id
}

\begin{abstract}
Sweet potato plant is one of the food crops that can be utilized by the community to fulfil the need for carbohydrates and vitamins. West Java province as one of the centres of production of this plant is considered to have a good cultivation potential, but lately, it has experienced decreasing land productivity caused by the depreciation of planting areas. The research was conducted in the Sub-district of Ciampea, Bogor, West Java. Research activities were conducted from December 2019 to February 2020. This research was carried out by physiographic method with an analytical approach that utilizes the soil map, where the research location was divided into 12 mapping units as a basis of ground check activities. The land suitability evaluation used the SPKL software application (Land Suitability Assessment System). Results showed that the cultivation of sweet potato in the sub-district of Ciampea was carried out on the marginally suitable lands (S3) and not suitable lands $(\mathrm{N})$ with limiting factors of annual rainfall, land-slope, and soil texture.
\end{abstract}

Keywords: geographic information system, land suitability assessment system, rainfall

\section{Pendahuluan}

Indonesia termasuk dalam salah satu negara padat penduduk yang memiliki laju pertumbuhan mencapai 1,49 persen per tahun (BPS, 2013). Adanya kenyataan ini berdampak pada peningkatan kebutuhan pangan domestik , sehingga dikhawatirkan ketersediaan pangan lokal bagi masyarakat semakin langka. Salah satu pilihan tanaman pangan yang dapat dikembangkan yaitu tanaman ubi jalar (Ipomoea batatas L.). Pengembangan budidaya tanaman ini sangat dianjurkan untuk mendukung diversifikasi pangan local bagi masyarakat. Hal ini dikarenakan ubi jalar memiliki kandungan karbohidrat dan nilai produktivitas cukup tinggi, potensi diversifikasi produk yang dinilai cukup beragam, permintaan pasar baik lokal maupun secara regional dinilai cukup berpotensi dan terus meningkat, serta kandungan gizi yang baik (ILO - PCdP2 UNDP, 2012). Kegiatan budidaya ubi jalar tentu saja harus harus disesuaikan dengan potensi sumberdaya lahan yang tersedia sehingga menghasilkan produksi yang baik. Komoditas ubi jalar di Kabupaten Bogor merupakan salah satu komoditas yang memiliki potensi produktvitas yang tinggi di Kecamatan Ciampea (Bappeda Kabupaten Bogor, 2014). Wilayah ini merupakan salah satu wilayah yang masuk dalam zona pengembangan ubi jalar, yaitu Zona III dimana terfokus pada kegiatan budidaya ubi jalar. Akan tetapi, pada saat ini produksi ubi jalar masih belum optimal. Hal ini diakibatkan adanya faktor pembatas yang menghambat pertumbuhan dan produksi ubi jalar. Adanya isu tersebut, maka kegiatan evaluasi lahan perlu dilakukan agar penggunaan 


\section{Jurnal Tanah dan Sumberdaya Lahan Vol 8 No 1: 273-279, 2021 \\ e-ISSN:2549-9793, doi: 10.21776/ub.jts1.2021.008.1.30}

serta pemanfaatan lahan dapat sesuai dengan potensi serta karakteristik lahannya. Sistem Informasi Geografi (SIG) saat ini telah dimanfaatkan untuk penetapan kebijakan pengembangan wilayah pertanian dan diintegrasikan dengan pemanfaatan program yang dikembangkan oleh Balai Besar Penelitian dan Pengembangan Sumberdaya Lahan Pertanian yaitu perangkat lunak SPKL (Sistem Penilaian Kesesuaian Lahan).

Integrasi antara SIG serta SPKL dalam menunjang kegiatan evaluasi lahan diharapkan dapat memberikan hasil berupa informasi mengenai tingkat kesesuaian lahan tanaman ubi jalar, menganalisis ketersediaan lahan untuk pengembangan ubi jalar, serta sebagai acuan dalam penyusuan arahan pengembangan tanaman ubi jalar. Hasil-hasil penelitian menunjukkan bahwa tanaman ubi jalar relatif tahan kekeringan dan tidak tahan genangan air dan curah hujan yang tinggi. Ubi jalar dapat dibudidayakan pada berbagai kondisi tanah, pengolahan tanah dilakukan dengan sistim guludan-berparit untuk menyediakan zone perakaran yang sesuai bagi perkembangan umbi (Ogbodo, 2005; Agbede et al., 2009; Agbede, 2010).

Penelitian ini dilakukan untuk menganalisis kesesuaian lahan dan faktor pembatas bagi budidaya ubi jalar di Kecamatan Ciampea, Kabupaten Bogor, Jawa Barat. Hasil penelitian ini diharapkan bermanfaat dalam memberikan suatu informasi mengenai kelas kesesuaian lahan bagi tanaman ubi jalar (Ipomoea batatas L.) dan faktor-faktor pembatasnya, sehingga lahan dapat dimanfaatkan secara berkelanjutan.

\section{Bahan dan Metode}

\section{Tempat dan waktu penelitian}

Penelitian ini dilaksanakan pada Bulan Desember 2019 sampai dengan Februari 2020, berlokasi di Kecamatan Ciampea, Kabupaten Bogor, Jawa Barat. Luas wilayah Kecamatan Ciampea sebesar 3352,06 ha. Berdasarkan data stasiun klimatogi Pos Dramaga pada tahun 2014 sampai dengan 2018 rata - rata curah hujan tahunan pada wilayah ini mencapai 2000 - $5000 \mathrm{~mm}$ per tahun, dengan suhu rata - rata tahunan sebesar $25,42{ }^{\circ} \mathrm{C}$ dan kelembaban rata -rata sebesar 80,44\%. Analisis data serta penyusunan peta dilakukan di Laboratorium Informasi Geospasial dan Analisis Sistem, Balai Besar Penelitian dan Pengembangan Sumberdaya Lahan Pertanian.

\section{Alat dan bahan}

Alat yang dimanfaatkan dalam kegiatan penelitian ini meliputi software Arcgis, software SPKL, Google Earth, jNSM (Java Newhall Simulation Model), Avenza Maps, KTT (Kunci Taksonomi Tanah), alat tulis, kamera, form pengamatan, laptop, sekop, cangkul, bor, $\mathrm{pH}$ universal, fial film, serta survey set. Bahan yang menunjang dalam kegiatan ini berupa citra Google Earth, citra SPOT 2018, Peta Rupa Bumi Indonesia (RBI), DEMNAS, Peta Tanah, Peta Kelerengan, Peta Penggunaan Lahan, data iklim tahun 2014 - 2018 yang diperoleh dari BMKG stasiun Dramaga, data produktivitas Kecamatan Ciampea 2019 yang diperoleh dari Bappeda Kabupaten Bogor, dan aquades.

\section{Pelaksanaan penelitian}

Penelitian ini memanfaatkan metode analisis terrain dan fisiografis karena dianggap paling sesuai dan efektif dalam kerangka penelitian ini. Peta yang dimanfaatkan untuk penentuan titik pengamatan berupa peta SPT (Satuan Peta Tanah) skala 1:50.000 Kabupaten Bogor tahun 2016 yang diperoleh dari BBSDLP. Metode analisis terrain dan fisiografis dilakukan dengan interpretasi DEMNAS berdasarkan bentuk wilayah dengan diikuti peninjauan lapang terhadap komposisi satuan peta. Analisis terrain adalah suatu analisis hidrologi untuk menghasilkan beberapa peta yang dimanfaatkan untuk penyusunan peta lainnya.

Pengamatan secara langsung dilakukan pada titik - titik pengamatan yang telah ditentukan dengan melakukan pengamatan minipit dan bor tanah. Data pengamatan lapangan ini digunakan untuk validasi data peta yang sudah dimiliki. Wawancara dengan beberapa petani ubi jalar dilakukan untuk memperoleh informasi tentang budidaya ubi jalar di lahan usahanya. Penilaian kesesuaian lahan dilakukan dengan memanfaatkan aplikasi SPKL yang telah dikembangkan oleh pihak BBSDLP. Aplikasi SPKL ini berguna untuk mempermudah melakukan kegiatan penilaian kesesuaian lahan terhadap potensi sumberdaya 


\section{Jurnal Tanah dan Sumberdaya Lahan Vol 8 No 1: 273-279, 2021 \\ e-ISSN:2549-9793, doi: 10.21776/ub.jts1.2021.008.1.30}

lahan dalam suatu daerah sehingga dapat menentukan pemanfaatan dan pengelolaannya secara berkelanjutan. Evaluasi kesesuaian lahan dilakukan dengan membandingkan karakteristik lahan aktual dengan syarat tumbuh tanaman ubi jalar yang telah dipublikasikan oleh BBSDLP (2011).

\section{Hasil dan Pembahasan}

\section{Karakteristik lahan di Kecamatan Ciampea}

Pertumbuhan dan produksi ubi jalar ditentukan oleh karakteristik lahan di lingkungan tumbuhnya. Berdasarkan kriteria syarat tumbuh tanaman ubi jalar (BBSDLP, 2011), kondisi agroklimat sangat menentukan pertumbuhan dan hasil umbi ubi jalar. Suhu udara pada lokasi penelitian dapat diketahui dari data iklim yang telah diperoleh. Curah hujan tahunan dan kelembaban udara mencerminkan karakteristik lahan yang mengindikasikan ketersediaan air dalam mendukung pertumbuhan dan produksi ubi jalar. Drainase lansekap setempat mempengaruhi ketersediaan oksigen di zone perakaran tanaman budidaya, tekstur tanah berperan pada pertumbuhan akar dan umbi, ketersediaan hara dicerminkan oleh derajat kemasaman $(\mathrm{pH})$ serta tingkat kejenuhan basa (KB), dan kemiringan lahan yang berkaitan dengan bahaya erosi yang dapat membatasi nilai kesesuaian lahan terhadap budidaya tanaman ubi jalar. Berdasarkan hasil analisis data suhu udara yang telah diperoleh dari Stasiun Klimatologi Pos Dramaga pada tahun 2014 hingga 2018 diketahui bahwa rata-rata suhu udara tahunan yang ada di lokasi penelitian sebesar $25.42^{\circ} \mathrm{C}$. Rata-rata curah hujan selama lima tahun terakhir adalah 3770,2 mm tahun ${ }^{-1}$ yang menunjukkan bahwa curah hujan dengan nilai tersebut masuk dalam kelas sesuai secara marjinal (S3) untuk budidaya tanaman ubi jalar. Hal ini sesuai dengan kriteria syarat tumbuh tanaman ubi jalar (BBSDLP, 2011) yang menunjukkan bahwa nilai curah hujan tahunan termasuk dalam kelas S3 ketika mencapai angka 2500-4000 mm/tahun. Berdasarkan hasil penelitian diketahui bahwa drainase yang tersebar pada lahan - lahan pertanian di Kecamatan Ciampea termasuk kelas baik, sedang, dan lambat. Menurut BBSDLP (2011), diketahui bahwa suatu drainase yang masuk dalam kelas sangat sesuai (S1) untuk pertumbuhan tanaman ubi jalar ketika kategorinya baik atau sedang, dan masuk dalam kelas kesesuaian lahan marjinal (S3) ketika drainase dalam kategori terhambat. Karakteristik lahan lainnya yang berdampak pada pertumbuhan tanaman adalah tekstur tanah. Tesktur tanah mempengaruhi pertumbuhan tanaman ubi jalar. Berdasarkan hasil kegiatan lapang, diketahui bahwa kelas tekstur tanah di wilayah Kecamatan Ciampea adalah liat berpasir, liat, liat berdebu yang masuk dalam kelas halus; lempung liat berpasir, lempung berliat masuk dalam kelas agak halus; lempung, lempung berdebu masuk dalam kelas sedang; dan lempung berpasir masuk dalam kelas agak kasar.

Tingkat kemasaman tanah dan nilai kejenuhan basa juga akan berdampak pada pertumbuhan tanaman sehingga perlu diketahui. Menurut Sudaryono (2009) kemasaman tanah merupakan faktor yang sangat penting karena berdampak pada kualitas tanah dan faktor penghambat untuk produksi tanaman karena perngaruhnya terhadap ketersediaan unsur hara. Berdasarkan hasil pengecekan $\mathrm{pH}$ secara langsung di lapangan diketahui bahwa nilai yang dihasilkan sebesar 5 - 6 dan diasumsikan memiliki nilai kejenuhan basa > 35\%. BBSDLP (2011) menjelaskan sesuai dengan syarat tumbuh tanaman ubi jalar bahwa ketika $\mathrm{pH}$ tanah bernilai 5,2 - 8,2 maka masuk dalam kelas sangat sesuai (S1) untuk pertumbuhan tanaman ubi jalar yang menandakan bahwa karakteristik ini bukan menjadi penghambat pertumbuhan tanaman di Kecamatan Ciampea. produktivitas ubi jalar pada tanah-tanah masam (Illava, 2001). Kondisi lereng (kemiringan lahan) yang tersebar di Kecamatan Ciampea beragam dari datar hingga bergunung yang didominasi oleh relief berombak dengan nilai 3 - 8\% yang ditemukan pada lahan - lahan pertanian. Berdasarkan kriteria syarat tumbuh BBSDLP (2011) nilai 3 $8 \%$ masuk dalam kelas cukup sesuai (S2) untuk tanaman ubi jalar.

\section{Kesesuaian lahan bagi tanaman ubi jalat dengan aplikasi SPKL}

Berdasarkan hasil analisis yang dilakukan sesuai dengan data hasil survei lapangan diketahui bahwa terdapat beberapa kelas kesesuaian 


\section{Jurnal Tanah dan Sumberdaya Lahan Vol 8 No 1: 273-279, 2021 e-ISSN:2549-9793, doi: 10.21776/ub.jts1.2021.008.1.30}

lahan. Kelas kesesuaian dominan adalah kelas S3 dengan faktor pembatas berupa curah hujan tahunan seluas 1867,02 ha, kemudian kelas S3 dengan faktor pembatas curah hujan tahunan dan lereng luasannya mencapai 282,99 ha, dan kelas $\mathrm{N}$ dengan pembatas lereng seluas 118,68 ha. Persebaran kelas kesesuaian lahan di Kecamatan Ciampea disajikan pada Gambar 1.

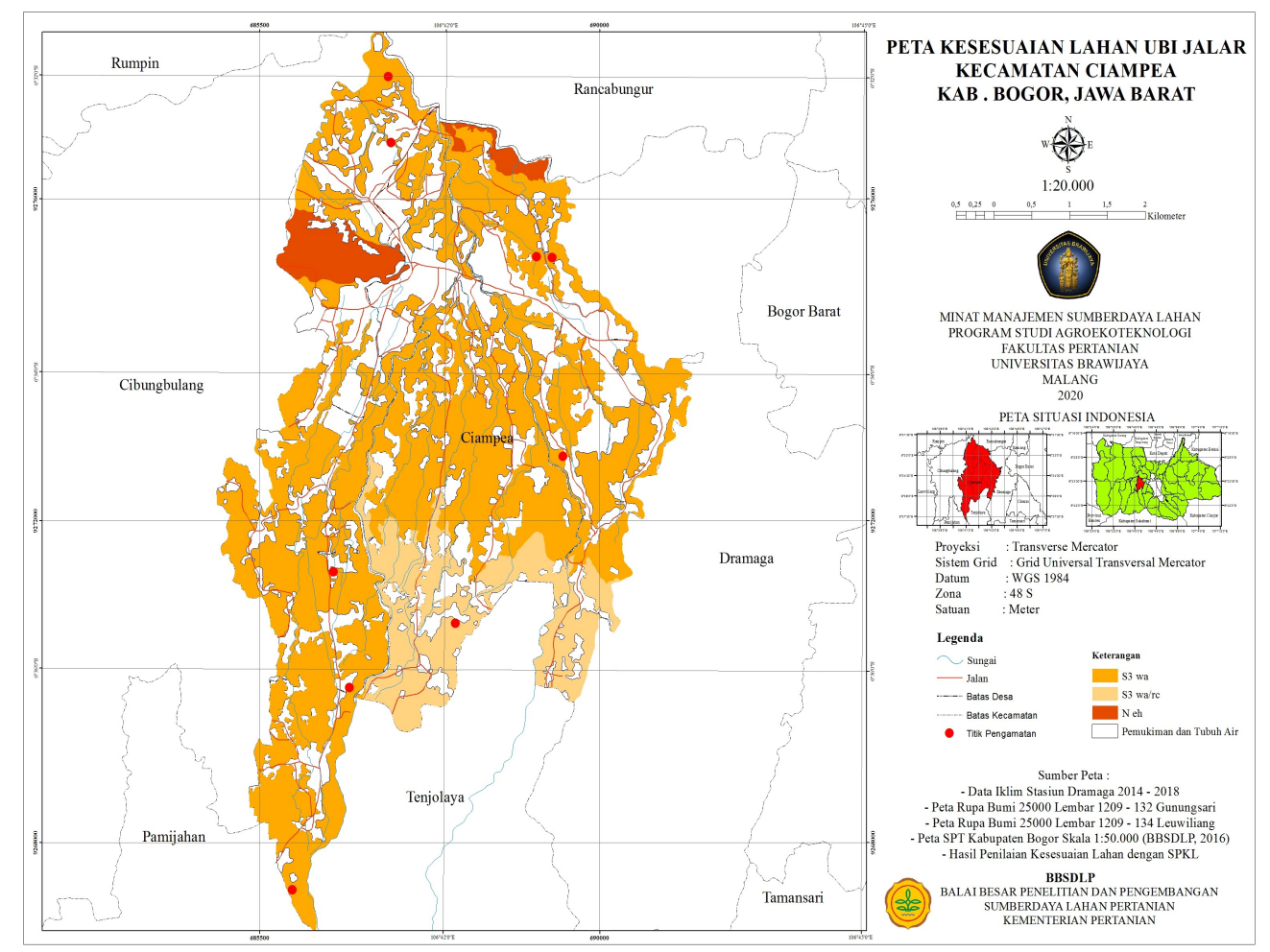

Gambar 1. Peta kesesuaian lahan Kecamatan Ciampea.

Curah hujan tahunan merupakan faktor pembatas utama yang ditemukan pada wilayah penelitian dan tentu saja akan berdampak pada produksi ubi jalar. Menurut Anwar et al. (2015), curah hujan sangat menentukan produksi tanaman ubi jalar. Curah hujan dan status lengas tanah selama pertumbuhan ubi jalar sangat menentukan hasil umbi (Gomes ¿i jalar relatif tahan kekeringan dan sangat tidak tahan terhadap kondisi tanah jenuh dan genangan air, terutama selama periode perkembangan umbinya (Chowdhury dan Naskar, 1993; Goswami, et al., 1995; Lin et al., 2006). Oleh karena itu biasanya pengolahan tanah dalam budidaya ubi jalar ditujukan untuk memperbaiki tata air dan tata udara (aerasi) tanah di zone perakaran tanaman (Howeler et al., 1993; Shi et al., 2002; Li et al., 2004; Jabro, et al., 2010). Adanya kelebihan air hujan selama pertumbuhan ubi jalar dapat diatasi dengan mengatur musim tanam, dimana sebaiknya penanaman ubi jalar pada lahan sawah dilakukan pada awal musim kemarau setelah tanaman padi, karena tanaman ubi jalar merupakan salah satu tanaman yang tidak memerlukan banyak air dan relative tahan kekeringan. Pada lahan kering tadah hujan, ubi jalar ditanam pada awal musim hujan (Oktober) atau akhir musim hujan (Maret) (Nedunchezhiyan dan Byju, 2005; Bourke, 2006; ILO - PCdP2 UNDP, 2012). Berdasarkan penilaian kesesuaian lahan ternyata kemiringan lahan menjadi faktor pembatas bagi budidaya tanaman ubi jalar. Hal ini dikarenakan kemiringan lahan di beberapa SPL mencapai > $40 \%$ dan lereng dengan nilai tersebut sudah tidak dapat diperbaiki untuk dimanfaatkan sebagai lahan budidaya pertanian. Hal ini sesuai 


\section{Jurnal Tanah dan Sumberdaya Lahan Vol 8 No 1: 273-279, 2021 \\ e-ISSN:2549-9793, doi: 10.21776/ub.jts1.2021.008.1.30}

dengan zonasi agroekologi berdasarkan kelas lereng, pemanfaatan lahan, serta jenis tanah; lereng sebesar $>40 \%$ termasuk dalam kategori zona I yang seharusnya hanya dimanfaatkan untuk hutan produksi ataupun hutan lindung (Syukur, 2005). Hasil wawancara dengan beberapa petani ubi jalar menunjukkan bahwa pada dalam budidaya ubi jalar ternyata aplikasi pupuk tidak sesuai dengan rekomendasi yang ada. Aplikasi pupuk oleh petani sangat beragam, sesuai dengan kemampuan petani untuk membeli pupuk dan biaya aplikasinya di lahan usaha. Dosis pupuk yang digunakan petani ubi jalar diperkirakan melebihi dosis pupuk yang direkomendasikan untuk budidaya ubi jalar, terutama pupuk urea. Selain penggunaan pupuk buatan, petani ubi jalar juga menggunakan pupuk kandang kambing dengan dosis yang berbeda-beda sesuai dengan jumlah pupuk kandang yang dimilikinya. Hasil-hasil penelitian menunjukkan bahwa pupuk $\mathrm{N}$ dan pupuk organik (pupuk kandang) mempengaruhi pertumbuhan dan hasil umbi ubi jalar (Hill et al., 1990; Villagarcia et al., 1998; Ankumah et al., 2003; Onunka et al., 2012; Sowley et al., 2015).

\section{Produktivitas ubi jalar}

Produktivitas tanaman ubi jalar di Kecamatan Ciampea berkisar 16,03 - 18,75 ton/ha, dimana nilai tertinggi terdapat pada Desa Cibuntu sebesar 18,75 ton/ha. Akan tetapi, di wilayah Kecamatan Ciampea terdapat beberapa desa yang belum membudidayakan tanaman ubi jalar. Data tersebut sesuai dengan hasil survei lapangan dimana ditemukan beberapa desa yang lahan pertaniannya tidak dimanfaatkan untuk penanaman ubi jalar melainkan untuk menanam ubi kayu. Desa - desa yang belum menghasilkan ubi jalar adalah Desa Ciampea, Desa Bojong Rangkas, dan Desa Cibadak.

Hasil perhitungan menunjukkan bahwa rata-rata produksi ubi jalar di lokasi penelitian berkisar 64-75\% dari potensi produksi ubi jalar kultivar lokal. Nilai produksi ini menunjukkan bahwa lahan usaha untuk budidaya ubi jalar di lokasi ini memiliki kesesuaian lahan setara dengan Kelas S2. Menurut kriteria (Mahi, 2015), jika nilai produksi tanaman di sebidang lahan mencapai $>80 \%$ potensi-produksi, maka lahan tersebut dalam kondisi sangat sesuai (S1), tidak diperlukan suatu input tambahan untuk memperbaiki kualitas lahan. Jika produksi mencapai 60-80\%, lahan tergolong kelas cukup sesuai (S2) untuk pertumbuhan tanaman tertentu serta perlunya input teknologi untuk memperbaiki kualitas lahan. Jika produksi sebesar 40-60\% maka ahan tergolong kelas sesuai marjinal (S3) oleh sebab itu diperlukan input teknologi yang diaplikasikan pada lahan tersebut dan lahan dalam kelas ini dinilai masih dianggap ekonomis dalam kondisi yang baik, dan jika produksi tanamannya $<40 \%$ potensi produksi suuatu tanaman, maka lahan tergolong kelas tidak sesuai $(\mathrm{N})$, menunjukkan bahwa faktor pembatas yang ada pada lahan tersebut masuk dalam kategori sangat berat.

Hasil evaluasi kesesuaian lahan berdasarkan produksi aktual ubi jalar di lahan petani (Kelas S2) berbeda dengan hasil evaluasi kesesuaian lahan berdasarkan data karakteristik lahan di aplikasi SPKL (Kelas S3). Perbedaan ini disebabkan oleh karena petani ubi jalar telah melakukan manajeman budidaya ubi jalar pada arah yang benar dan tindakan manajemen budidaya yang dilakukan petani ini belum dimasukkan ke dalam aplikasi SPKL. Hal ini membuktikan bahwa tindakan pengelolaan yang dilakukan petani ubi jalar setempat merupakan salah satu upaya yang berhasil dalam meningkatkan produksi ubi jalar. Guludan - guludan dengan parit-parit di antara guludan dapat membantu mengatasi efek negatif dari genangan air hujan terhadap hasil umbi. Selain itu para petani ubi jalar sudah berpengalaman kapan waktu menanam ubi jalar dalam setahun untuk menghindari curah hujan yang berlebihan (King, 1985; Ganno et al., 1997; Agbede dan Adekiya, 2011; Chagonda et al., 2014; Dumbuya et al., 2016; Janeth et al., 2019).

\section{Kesimpulan}

Kelas kesesuaian lahan bagi tanaman ubi jalar di Kecamatan Ciampea dengan menggunakan aplikasi SPKL adalah cukup sesuai secara marjinal (S3) dan tidak sesuai (N), faktor pembatasnya adalah curah hujan tahunan yang terlalu tinggi. Rekomendasi untuk mengatasi faktor pembatas dalam budidaya tanaman ubi jalar di Kecamatan Ciampea adalah pengolahan tanah dengan sistem guludan-berparit, dimana guludan cukup tinggi $(30-50 \mathrm{~cm})$ dan parit- 


\section{Jurnal Tanah dan Sumberdaya Lahan Vol 8 No 1: 273-279, 2021 e-ISSN:2549-9793, doi: 10.21776/ub.jts1.2021.008.1.30}

paritnya cukup dalam. Selain itu saat tanam ubi jalar disesuaikan dengan kondisi curah hujan, sehingga selama fase perkembangan dan pemasakan umbi tidak terjadi hujan yang berlebihan.

\section{Ucapan Terima Kasih}

Terima kasih disampaikan kepada BBSDLP yang telah membantu serta mendukung jalannya kegiatan penelitian. Penulis juga menyampaikan terima kasih kepada masyarakat di Kecamatan Ciampea yang telah memberikan ijin dalam pengumpulan data penelitian.

\section{Daftar Pustaka}

Agbede, T. M. 2010. Tillage and fertilizer effects on some soil properties, leaf nutrient concentrations, growth and sweet potato yield on an Alfisol in southwestern Nigeria. Soil and Tillage Research 110(1): 25-32.

Agbede, T. M., and Adekiya, A. O. 2009. Tillage effects on soil properties and performance of sweet potato on an Alfisol in Southwestern Nigeria. American-Eurasian Journal of Sustainable Agriculture 3(3): 561-568.

Agbede, T. M., and Adekiya, A. O. 2011. Evaluation of sweet potato (Ipomoea batatas L.) performance and soilproperties under tillage methods and poultry manure levels. Emirates Journal of Food and Agriculture, p.164-177.

Ankumah, R. O., Khan, V., Mwamba, K., and Kpomblekou-A, K. 2003. The influence of source and timing of nitrogen fertilizers on yield and nitrogen use efficiency of four sweet potato cultivars. Agriculture, ecosystems and environment 100(2-3): 201-207.

Anwar, M. R., Liu, D. L., Farquharson, R., Macadam, I., Abadi, A., Finlayson, J., Wang, B., Ramilan, T. 2015. Climate Change Impacts on Phenology and Yields of Five Broadacre Crops at Four Climatologically Distinct Locations in Australia. Agricultural Systems, 132, 133- 144.

Bappeda Kabupaten Bogor, 2014. Bappeda Kabupatren Bogor.

BBSDLP. 2011. Petunjuk Teknis Evaluasi Lahan untuk Komoditas Pertanian. Balai Besar Penelitian dan Pengembangan Sumberdaya Lahan Pertanian. Bogor.

Bourke, R. M. 2006. Differences between calendar time and plant time in sweet potato: a potential source of significant experimental error. In 14th Triennial Symposium of International Society of Tropical Root Crops (pp. 20-26).
BPS. 2013. Badan Pusat Statistik, Jakarta.

Chagonda, I., Mapfeka, R. F., and Chitata, T. 2014. Effect of tillage systems and vine orientation on yield of sweet potato (Ipomoea batatas L.). American Journal of Plant Sciences 5(21): 31-59.

Chowdhury, S. R., and Naskar, S. K. 1993. Screening of drought tolerant traits in sweet potato: Role of relative water content. Orissa Journal of Horticulture 21: 1-4.

Dumbuya, G., Sarkodie-Addo, J., Daramy, M. A., and Jalloh, M. 2016. Growth and yield response of sweet potato to different tillage methods and phosphorus fertilizer rates in Ghana. Journal of Experimental Biology 4(5): xx.

Ganno, K., Kihou, N., Ikoma, H., and Imazono, S. 1997. A low cost ridge hammering tillage system for high quality production of sweet potato. In Plant Nutrition for Sustainable Food Production and Environment (pp. 959-960). Springer, Dordrecht.

Gomes, F., and Carr, M. K. V. 2001. Effects of water availability and vine harvesting frequency on the productivity of sweet potato in Southern Mozambique. I. Storage root and vine yields. Experimental Agriculture 37(4): 523-537.

Gomes, F., and Carr, M. K. V. 2003. Effects of water availability and vine harvesting frequency on the productivity of sweet potato in southern Mozambique. II. Crop water use. Experimental Agriculture 39(1): 39-54.

Goswami, S. B., Sen, H., and Jana, P. K. 1995. Tuberization and yield potential of sweetpotato cultivars as influenced by water management practices. Journal of Root Crops 21(2): 77-81.

Hill, W.A., Hortense, D., Hahn, S. K., Mulongoy, K., and Adeyeye, S.O. 1990. Sweet potato root and biomass production with and without nitrogen fertilization. Agronomy Journal 82(6): 1120-1122.

Howeler, R. H., Ezumah, H. C., and Midmore, D. J. 1993. Tillage systems for root and tuber crops in the tropics. Soil and Tillage Research 27(1-4): 211-240.

Ila'Ava, V. P. 2001. Sweet Potato Research in Acid Soils. Food Security for Papua New Guinea: Proceedings. Australian Centre for International Agricultural Research (ACIAR). Canberra, p.724-729.

ILO - PCdP2 UNDP. 2012. Laporan Studi: Kajian Ubi Jalar dengan Pendekatan dan Iklim Usaha di Kabupaten Jayawijaya.

Jabro, J. D., Stevens, W. B., Iversen, W. M., and Evans, R. G. 2010. Tillage depth effects on soil physical properties, sugarbeet yield, and sugarbeet quality. Communications in soil science and plant analysis 41(7): 908-916. 


\section{Jurnal Tanah dan Sumberdaya Lahan Vol 8 No 1: 273-279, 2021}

e-ISSN:2549-9793, doi: 10.21776/ub.jts1.2021.008.1.30

Janeth, C., Karuku, G. N., Onwonga, R. N., and Kathumo, V. M. 2019. Effects of Tillage Practices and Organic Cropping Systems on the Yield of Sorghum (sorghum bicolor L.) and Sweet Potato (Ipomoea batatas L) in Yatta SubCounty, Kenya. Journal of Agriculture and Sustainability 12(2): xx.

King, G. A. 1985. The effect of time of planting on yield of six varieties of sweet potato (Ipomoea batatas (L.) Lam.) in the southern coastal lowlands of Papua New Guinea. Tropical agriculture 62(3): 225-228.

Li, J., Li, C., Liu, X., Zhang, L., Zhang, W., Wang, W., Cao, S. and Wang, Y. 2004. Effects of soil aeration on potato yield and its physiological mechanism. Zuo wu xue bao 30(3): 279-283.

Lin, K. H., Chao, P. Y., Yang, C. M., Cheng, W. C., Lo, H. F., and Chang, T. R. 2006. The effects of flooding and drought stresses on the antioxidant constituents in sweet potato leaves. Botanical Studies, 47(4): 417-426.

Mahi, A.K. 2015. Survei Tanah: Evaluasi dan Perencanaan Penggunaan Lahan Edisi 2. Yogyakarta, Graha Ilmu.

Nedunchezhiyan, M., and Byju, G. 2005. Effect of planting season on growth and yield of sweet potato (Ipomoea batatas L.) varieties. J. Root Crops, 31(2): 111-114.

Ogbodo, E. N. 2005. Effect of depth of tillage on soil physical conditions, growth and yield of sweet potato in an Ultisol at Abakaliki, Southeastern Nigeria. Journal of Agriculture and Social Research 5(1): 41-47.
Onunka, N. A., Chukwu, L. I., Mbanasor, E. O., and Ebeniro, C. N. 2012. Effect of organic and inorganic manures and time of application on soil properties and yield of sweetpotato in a tropical ultisoL. Journal of Agriculture and Social Research (JASR), 12(1): 183-194.

Shi, C., Wang, Z., Guo, F., and Yu, S. 2002. Effects of the soil aeration on nutrient absorption, 14 C-assimilates distribution and storage root yield in sweet potato. Acta Agriculturae Nucleatae Sinica 16(4): 237-241.

Sowley, E. N. K., Neindow, M., and Abubakari, A. H. 2015. Effect of poultry manure and NPK on yield and storability of orange-and white-fleshed sweet potato [Ipomoea batatas (L.) Lam]. ISABB Journal of Food and Agricultural Sciences 5(1): 1-6.

Sudaryono. 2009. Tingkat Kesuburan Tanah Ultisol pada Lahan Pertambangan Batubara Sangatta Kalimantan Timur. Jurnal Teknik Lingkungan 10 (3): $337-346$.

Syukur, A. 2005. Pengaruh Pemberian Bahan Organik terhadap Sifat-Sifat Tanah dan Pertumbuhan Caisin di Tanah Pasir Pantai. J. Ilmu Tanah dan Lingkungan 5(1): 30-38.

Villagarcia, M. R., Collins, W. W., and Raper, C. D. 1998. Nitrate uptake and nitrogen use efficiency of two sweetpotato genotypes during early stages of storage root formation. Journal of the American Society for Horticultural Science 123(5): 814-820. 